\title{
The Perception, Significance, Yield Gap and Market Clarity of Organic Farming in the Backdrop of Ecological Balance
}

\author{
M. Priyadharshini ${ }^{1^{*}}$ and J. Venkatapirabu ${ }^{2}$ \\ ${ }^{I}$ Department of $A E \& R S, T N A U$, Coimbatore, India \\ ${ }^{2}$ Planning and Monitoring, TNAU, Coimbatore, India \\ *Corresponding author
}

\section{A B S T R A C T}

\section{Keywords}

Perception, Significance, Organic farming, Inorganic farming

Article Info

Accepted:

12 February 2019 Available Online: 10 March 2019
The study was undertaken to find out the perception and significance of organic and inorganic farming in Coimbatore district. Majority $(57.78 \%)$ of the organic vegetable growers had high level of perception on organic farming, followed by medium $(26.67 \%)$ and low $(15.56 \%)$ of perception level of organic farming. Majority of the inorganic vegetable growers had medium $(30.00 \%)$ level of perception in inorganic farming, followed by high $(10.00 \%)$ and low $(5 \%)$ level of perception of inorganic farming respectively. Hence, majority of the vegetable growers had high level of perception in organic farming practices and medium inorganic farming practices. Nearly half $(53.33 \%)$ of the respondents had medium level significance, followed by high and low level of significance $(33.33 \%)$ and $(13.33 \%)$. regarding inorganic vegetable growers, $(80 \%)$ of the respondent had medium level of significance, followed by high and low level with $(13.33 \%)$ and $(6.67 \%)$ respectively.

\section{Introduction}

The inability of Indian agriculture to meet the demand for food in the country during the two and half decades immediately after independence had been a matter of concern at those times. The system of our agriculture based on the traditional knowledge and practices handed down from generation to generation could not produce enough to feed the increasing population. The green revolution fulfilled our aspirations by changing India from a food importing to a food exporting nation (Narayanan, 2005)
The practice of organic farming, said to the best known alternative to the conventional method, also originated in the west, which suffered from the ill effects of chemical agriculture. However, organic farming is based on the similar principles underlying our traditional agriculture. Organic agriculture aims at the human welfare without any harm to the environment which is the foundation of human life itself.

Farmers interested in organic farming would, therefore, look first at the older Indian (and Chinese) agricultural practices, still followed in some parts of the country. Modern 
agriculture in India is hardly 50 years old and green revolution was introduced more recently in 1966. In contrast, agricultural practices of India date back to more than 4000 years. This has maintained the soil fertility status over that enormously long period of time.

Most of the traditional practices are propagated in many forms such as proverbs, folksongs, rituals, riddles and several other traditions. The farmers of ancient India adhered to the natural laws while developing farming systems and practices.

Farmers in the Vedic period possessed a fair knowledge about soil fertility, selection of seeds, plant protection, and seasons of sowing and suitability of crops in different lands which are mentioned in Arthashastra. Varahamitra mentioned different types of seed sowing as well as seed treatment and crop protection practices

The increased use of inorganic fertilizers were deemed necessary: (i) to increase production per unit of land in the face of a growing shortage of arable land in many developing countries, (ii) to increase marketed food supplies or exports, and (iii) to raise incomes and return to labor. Furthermore inorganic fertilizers were needed to make full use of the new high-yielding varieties. The combined package of new crop varieties, pests and disease control and the use of inorganic fertilizers caused a dramatic increase in crop yields in many parts of the tropics. This was particular the case in India.

\section{Materials and Methods}

The present study was conducted in Coimbatore district. Among nine taluks in Coimbatore district, Coimbatore south taluk was selected purposively for the study, since more areas were brought under vegetable cultivation. Thondamuthur block was purposively selected for study of farmers growing tomato under organic farming condition, because Organic Farming Association was effectively functioning in this area and the nearby villages were selected for the inorganic vegetable growers. These villages were selected for the study as they were possessing large area under vegetable cultivation. The list of organic and inorganic vegetable growers was collected from the Directorate of organic seed certification office in Coimbatore district. A sample of 90 vegetable growers was considered for the study which includes 45 organic and 45 inorganic farmers. From each selected villages, 30 farmers were selected giving equal importance to organic and inorganic farmers by employing simple random sampling method.

\section{Results and Discussion}

The following details furnish about the following features

Perception towards organic farming

Significance of organic farming

Yield gap

Market clarity

\section{Perception towards organic farming}

Perception is an act or power of perceiving or apprehending or combining the sensations into recognition of an object or stimulus. The perception on organic manures was operationalized as the power of perceiving organic manure in relation to eco-logical significance by the respondents.

The distribution of respondents according to their perception on organic manures is furnished in Table 1. The results shows that majority $(57.78 \%)$ of the organic vegetable growers had high level of perception on 
organic farming, followed by medium (26.67 $\%)$ and low (15.56\%) of perception level of organic farming.

The reason behind this was they realized the importance of organic farming, its benefits for the consumers. They perceived that organic farming improves the soil health, and it delivers good produce. The other important thing was they are getting less yield and income initially. But reason for following was to have healthy life and make a good environment they are following organic farming.

Mostly medium farmers are the group they are following organic farming. They are having separate community, monthly meeting will be conducted in each village. In that day doubts or any new technologies would be shared and by this the organic farming gets benefited.

\section{Perception towards inorganic farming}

The distribution of respondents according to their perception on inorganic manures is furnished in Table 2. From this table it represents that majority of the inorganic vegetable growers had medium $(30.00 \%)$ level of perception in inorganic farming, followed by high $(10.00 \%)$ and low $(5.00 \%)$ level of perception of inorganic farming respectively.

The reason behind this was they are following inorganic farming only for the income, the growth and yield will be, more they will get immediate results even they know the disadvantage but to get income they are following inorganic farming.

\section{Significance of organic farming}

Significance of organic farming refers to the importance of organic farming how the crops cultivated without the use of chemical either pesticides, fertilizer or of any kind. Organic proponents cite evidence showing that certain chemicals used in conventional farming, including pesticides and herbicides, mimic hormones - usually estrogen - when inside a person.

They claim that this is significant even at the minute levels that the average person is exposed to. Choosing organically grown fruits and vegetables can significantly decrease the frequency and level of dietary exposure to pesticides, thus reducing the magnitude of one risk factor that can contribute to a variety of health problems. Epidemiological evidence has confirmed that diets rich in fruits and vegetables are associated with reduced frequency and severity of several health problems.

Organic farming methods can increase concentrations of antioxidants and nutritional values in vegetables, fruits, grains, and dairy products, and in this way help people elevate their daily antioxidant intake without a proportional rise in calories.

The details with respect to distribution of respondents according to their under three categories are presented in Table 3.

From the Table 3, it represents that 53.33 per cent of the respondents had known the significance to a moderate level, followed by high and low levels $(33.33 \%)$ and $(13.33 \%)$. Regarding inorganic vegetable growers, 80.00 per cent of the respondent had medium level of significance, followed by high and low level with 13.33 per cent and 6.67 per cent respectively.

The reason for moderate level in organic farming as farmers would not get immediate results, the profit, yield will less when it is compared to inorganic farming. Regarding inorganic the reason behind this was, they 
will get immediate results but it affects the soil health, fertility even they got awareness that is health hazards due to the application of inorganic nutrients hence its in the moderate level. This finding is in accordance with the findings of Greene (2000) who stated that more than half of the vegetable farmers had high degree of significance.

\section{Yield gap}

The concept of a yield gap is frequently used in technical agronomic analysis of production as a measure of performance because it implies $\mathrm{s}$ a comparison between yields actually obtained under particular agro ecological conditions on commercial farms and the maximum or potential yield in that region. The potential yield is determined by producing the crop without constraints that are normally found at the farm level, such as nutrient and water stress, inadequate cultivation practices, and so on.

The details with respect to distribution of respondents according to their yield gap of organic and inorganic application of nutrients under three categories are presented in Table 4. From this Table 4, it represents that majority of the respondents comes under medium level $(51.11 \%)$ followed by low (35.56\%) and high level 13.33 per cent of yield gap respectively. Regarding inorganic vegetable growers majority of the respondents were medium level 51.11 per cent along with low and high level 31.11 per cent and 17.78 per cent respectively. The findings derived from the findings of Eurostat (2007).

\section{Market clarity}

Market perception refers to, the process by which an individual selects, organize and interpret stimuli into a meaningful and coherent picture of the world. Market perception of the farmers was measured with the help of the following questions on the need of marketing, prevailing price and the difficulties in marketing of the organic produce.

The questions and the scoring procedure adopted by Somasundaram (1976) were used. The questions were slightly modified to suit to organic farming. The distribution of respondents according to their market clarity is given in the Table 5 .

The result reveals that 37.78 per cent of the organic vegetable growers had medium level of market clarity, followed by low 33.33 per cent and high 28.89 per cent level of market clarity. With regard to inorganic vegetable growers, 44.44 per cent had high level of market clarity, followed by medium 33.33 per cent and low 22.22 per cent levels of market clarity. This finding is in accordance with the findings of Anand (2003) who stated that more than half of the vegetable growers had high degree of market clarity.

Table.1 Distribution of respondents based on their perception towards organic farming

\begin{tabular}{|l|l|l|l|}
\hline S. No. & Category & \multicolumn{2}{|c|}{ Organic farmers $(n=45)$} \\
\cline { 3 - 4 } & & Number & Per cent \\
\hline $\mathbf{1}$ & Low & 7 & $\mathbf{1 5 . 5 6}$ \\
\hline $\mathbf{2}$ & Medium & 12 & $\mathbf{2 6 . 6 7}$ \\
\hline $\mathbf{3}$ & High & 26 & $\mathbf{5 7 . 7 8}$ \\
\hline & Total & $\mathbf{4 5}$ & $\mathbf{1 0 0 . 0 0}$ \\
\hline
\end{tabular}


Table.2 Distribution of respondents based on their perception towards Inorganic Farming

\begin{tabular}{|l|l|l|l|}
\hline S. No. & Category & \multicolumn{2}{|l|}{ Inorganic farmers(n=45) } \\
\cline { 3 - 4 } & & Number & Per cent \\
\hline $\mathbf{1}$ & Low & 5 & $\mathbf{1 1 . 1 1}$ \\
\hline $\mathbf{2}$ & Medium & 30 & $\mathbf{6 6 . 6 7}$ \\
\hline $\mathbf{3}$ & High & 10 & $\mathbf{2 2 . 2 2}$ \\
\hline & Total & $\mathbf{4 5}$ & $\mathbf{1 0 0 . 0 0}$ \\
\hline
\end{tabular}

Table.3 Distribution of respondents based on their significance of organic farming

\begin{tabular}{|l|l|l|l|l|l|}
\hline S. No. & Category & \multicolumn{2}{|c|}{ Organic farmers $(\mathbf{n}=45)$} & \multicolumn{2}{l|}{ Inorganic farmers $(\mathbf{n}=45)$} \\
\cline { 3 - 6 } & & Number & Per cent & Number & Per cent \\
\hline $\mathbf{1}$ & Low & 6 & 13.33 & 3 & $\mathbf{6 . 6 7}$ \\
\hline $\mathbf{2}$ & Medium & 24 & 53.33 & 36 & $\mathbf{8 0}$ \\
\hline $\mathbf{3}$ & High & 15 & 33.33 & 6 & $\mathbf{1 3 . 3 3}$ \\
\hline & Total & $\mathbf{4 5}$ & $\mathbf{1 0 0 . 0 0}$ & $\mathbf{4 5}$ & $\mathbf{1 0 0 . 0 0}$ \\
\hline
\end{tabular}

Table.4 Distribution of respondents based on their yield gap

\begin{tabular}{|l|l|l|l|l|l|}
\hline \multirow{2}{*}{ S. No. } & Category & \multicolumn{2}{|c|}{ Organic farmers(n=45) } & \multicolumn{2}{l|}{ Inorganic farmers $(\mathbf{n}=45)$} \\
\cline { 3 - 6 } & & Number & Per cent & Number & Per cent \\
\hline $\mathbf{1}$ & Low & 16 & 35.56 & 14 & $\mathbf{3 1 . 1 1}$ \\
\hline $\mathbf{2}$ & Medium & 23 & 51.11 & 23 & $\mathbf{5 1 . 1 1}$ \\
\hline $\mathbf{3}$ & High & 6 & 13.33 & 8 & $\mathbf{1 7 . 7 8}$ \\
\hline & Total & $\mathbf{4 5}$ & $\mathbf{1 0 0 . 0 0}$ & $\mathbf{4 5}$ & $\mathbf{1 0 0 . 0 0}$ \\
\hline
\end{tabular}

Table.5 Distribution of respondents based on their market clarity

\begin{tabular}{|l|l|l|l|l|l|}
\hline S. No. & Category & \multicolumn{3}{|c|}{ Organic farmers(n=45) } & \multicolumn{2}{l|}{ Inorganic farmers(n=45) } \\
\cline { 3 - 6 } & & Number & Per cent & Number & Per cent \\
\hline $\mathbf{1}$ & Low & 15 & 33.33 & 10 & $\mathbf{2 2 . 2 2}$ \\
\hline $\mathbf{2}$ & Medium & 17 & 37.78 & 15 & $\mathbf{3 3 . 3 3}$ \\
\hline $\mathbf{3}$ & High & 13 & 28.89 & 20 & $\mathbf{4 4 . 4 4}$ \\
\hline & Total & $\mathbf{4 5}$ & $\mathbf{1 0 0 . 0 0}$ & $\mathbf{4 5}$ & $\mathbf{1 0 0 . 0 0}$ \\
\hline
\end{tabular}

In conclusion, an increase in investment and research in organic agriculture is needed. Large scale production of biofetilizers and biocontrol agents units must be established and new programmes should be formulated to increase the availability of seeds of green manure crops. Awareness campaigns on the benefits of organic farming should be organized and there should be proper publicity and propaganda through mass media about the importance and need for organic farming. Proper training and Implementation of organic agriculture practices through properly structured research and aggressive extension programmes should be made. Special insurance scheme for organic farming 
to reduce the risk in case of failure of crop. Strong linkages between growers and consumers with minimum influence of middle men should be developed.

Efforts are needed to strengthen information and communication capacities of farmers through training courses and collaborative arrangements with local and state level organizations.

Majority of the respondents were educated upto middle school level, therefore facilities can be created in the villages for higher education. Extension workers can make use of the high levels of farming experience, extension agency contact and mass media exposure to disseminate the organic farming practices among vegetable growers and self help group members.

Majority of the vegetable growers felt the lack of proper marketing channel and lack of price policy as their constraints. Hence, the government can give priority in establishment of proper marketing channel for organic vegetables produce to prevent the intervention of intermediaries and to ensure a better price.

\section{References}

Anand, G. 2003. Marketing Behaviour of Banana Growers of Thiruchirapalli
District. M.Sc. (Ag.) Thesis, TNAU, Coimbatore.

Eurostat, 2007. Statistics in focus. Different organic farming patterns within EU25. An overview of the current situation

Greene, K. 2000. U.S. Agriculture Gaining Ground. Agricultural Outlook, Vol. 2 (April).

IFOAM. 2000. Organic Agriculture and Fair Trade: Two Concepts Based on the Same Holistic Principal. Online report. International Federation of Organic Agriculture Movements. Germany. Available at: www.ifoam.org.

Kerlinger, F.N.1964. Foundations of Behavioural Research, New York: Holt, Rinehart and Winston, Inc.

Kerlinger, F.N. 1983. Foundations of Behavioural Research, New Delhi. Surject Publications: 25.

Narayanan, S. 2005.Organic Farming in India: Relevance, Problems and Constraints. National Bank for Agriculture and rural development. Mumbai.

Somasundaram, D. 1976. A Diagnostic study of Small Farmers to New Agricultural Technologies and its Effective Communication for Adoption. Unpub. M.Sc. (Ag.) Thesis, TNAU, Coimbatore.

\section{How to cite this article:}

Priyadharshini, M. and Venkatapirabu, J. 2019. The Perception, Significance, Yield Gap and Market Clarity of Organic Farming in the Backdrop of Ecological Balance. Int.J.Curr.Microbiol.App.Sci. 8(03): 1203-1208. doi: https://doi.org/10.20546/ijcmas.2019.803.142 